\title{
Age-related dendritic and spinal alterations of pyramidal cells of the human visual cortex
}

\author{
Ioannis A. Mavroudis ${ }^{1,2}$, Marina G. Manani ${ }^{1}$, Foivos Petrides ${ }^{1}$, Dimitrios Dados $^{1}$, Alin Ciobica ${ }^{3,4}$, \\ Manuela Padurariu ${ }^{3,5}$, Konstantina Petsoglou ${ }^{6}$, Samuel N. Njau ${ }^{6}$, Vasiliki G. Costa ${ }^{1,2}$, Stavros J. Baloyannis ${ }^{1,2}$ \\ ${ }^{1}$ Laboratory of Neuropathology, First Department of Neurology, AHEPA Hospital, Aristotelian University of Thessaloniki, Greece, \\ ${ }^{2}$ Institute for Alzheimer's Disease Research, Heraklion Langada, Greece, "3"Alexandru Ioan Cuza” University, Iasi, Romania, \\ ${ }^{4}$ Center of Biomedical Research of the Romanian Academy, lasi Branch, Romania, " “Gr. T. Popa” University of Medicine \\ and Pharmacy, lasi, Romania, ${ }^{6}$ Laboratory of Forensic Medicine and Toxicology, Aristotelian University of Thessaloniki, Greece
}

\begin{abstract}
Introduction: Normal aging is characterized by deterioration of visual abilities, affecting mainly visual acuity, contrast and wavelength sensitivity. In the present study we attempted to describe the morphological and morphometric alterations of the dendrites and the dendritic spines of the pyramidal cells of the visual cortex during normal aging, in order to approach the visual impairment of aged individuals from a neuropathological point of view.

Material and methods: We studied the visual cortex in 20 brains using the Golgi technique.

Results: In pyramidal cells, which represent the majority of cortical neurons, age-related pathology can be observed in cell somata as well as, most importantly, in dendrite number and morphology. The apical dendrites of some pyramidal cells are distorted and tortuous. Horizontal dendritic arborization is also severely decreased. These alterations were more prominent in the corticocortical pyramidal neurons of the $5^{\text {th }}$ layer.

Conclusions: The morphological and morphometric assessment of the dendrites and the dendritic spines in the visual cortex in normal aging revealed substantial alterations of the dendritic arborization and marked loss of the dendritic spines, which may be related to visual impairment even in normal aging.
\end{abstract}

Key words: visual cortex, ageing, pyramidal cells, 3D neuronal reconstruction, Golgi method.

\section{Introduction}

Normal aging is characterized by deterioration of visual abilities, affecting mainly visual acuity, contrast and wavelength sensitivity $[14,28,38,47,50,63]$. Anatomical and morphological studies concluded that retinal abnormalities and changes of the subcor- tical areas do not efficiently explain the perceptual deficits $[1,27,50]$, and recent neuroimaging studies suggest that age-related dedifferentiation may apply at a neural level besides photoreceptors [1].

Several conflicting lines of evidence exist so far concerning the possible causative mechanism for such impairment. Hua et al. (2006) described signif- 
icant functional degradation of the primary visual cortex in aged animals, which could be regarded as direct evidence for the loss of function in visual cortical cells [19].

Although a decrease in brain size has been reported with increasing age [11], there is some evidence that gray matter tissue loss is minimal in patients without degenerative abnormalities [12]. Brody (1955) and Samorajski (1976) in their early studies mentioned a significant neuronal loss during normal ageing [7,49], whereas Pakkenberg and Gundersen (1997) in a more recent study suggested a small loss of neurons with age [42]. The latter findings are in agreement with studies of Vincent et al. (1989), Peters and Sethares (1993) and Tiggers et al. (1990), who concluded that there is no significant loss of neurons during ageing.

According to light microscopy, no significant changes in length and complexity of the dendritic arbor were found to correlate with age-related functional alterations $[5,10,36,55]$ in layer I of rhesus monkeys. However, electron microscopy revealed fewer dendritic and spine profiles per unit area, thickening of the glia limiting membrane and a concomitant decrease in the numerical density of synapses with age [44]. Furthermore, Xu et al. (2007) in a Golgi study in rats, revealed age-related changes in dendritic branching and spinal density of the pyramidal cells of the visual cortex [65].

In order to further examine the possible age-related alterations in the human visual cortex, we focused on the pyramidal cells of layer 5 of the human visual cortex. Two main classes of pyramidal neurons have been described in layer 5 , each of them playing a unique role in visual information processing. The first one refers to corticocortical pyramidal neurons. Corticocortical pyramidal neurons have short apical dendrites which never reach higher than layers $2 / 3$, small to medium sized cell bodies and a few basal dendrites. Corticocortical neurons participate in direct feedback circuits [8].

The second type of pyramidal neurons refers to corticotectal neurons, which have large cell somata, a long apical dendrite forming a large terminal tuft in layer 1, and their basal dendrites form a dense and symmetrical dendritic field [8].

These cells bear fast-conducting axons that branch to enervate multiple subcortical targets and intracortical collaterals that may end several millimeters away from the soma $[15,26,54]$. In the pri- mary visual cortex (V1), the great majority of corticotectal neurons are members of this distinctive subpopulation of pyramidal neurons $[25,47,58]$. Corticotectal neurons of V1 terminate in superficial, retinal recipient layers of the superior colliculus in a roughly topographic manner $[16,17]$.

Thus there are two morphologically distinct projection systems in layer 5 , one projecting to cortical and the other one to subcortical targets, suggesting that these two systems transmit different information from the visual cortex.

In previous studies we have shown significant dendritic and spinal changes in the visual cortex during normal ageing [33] and in Alzheimer's disease [32]. In the present study we attempted to describe the morphological and morphometric alterations of the dendrites and the dendritic spines of the pyramidal cells of the visual cortex during normal aging, in order to approach the visual impairment of aged individuals from a neuropathological point of view.

\section{Material and methods \\ Subjects}

Tissue samples from 20 brains were provided by the Laboratory of Forensic Medicine and Toxicology. Tissue blocks were removed post-mortem and immediately immersed in $10 \%$ buffered formalin solution. All the brains had been examined using routine histopathology methods and no macroscopic or microscopic signs of underling pathology were observed. The brains were divided into two groups, the first of them consisting of ten individuals aged $40-55$ years and the second consisting of the remaining ten aged 75-86 years.

\section{Tissue preparation}

Tissue samples of the primary visual cortex were excised from the left hemisphere, stained with a modified Golgi method and cut in a slicing microtome in thick sections at the range of $150 \mu \mathrm{m}$.

\section{Cell selection criteria}

Neurons examined consequently for quantitative alterations met the criteria set forth by Jacobs et al. (1997) that request uniform staining of neuronal processes, absence of precipitated debris, good contrast between cells and background, and relatively uniform tissue thickness [22]. 


\section{Neuronal tracing and variables analyzed}

For each one of 20 brains, 30 pyramidal cells of the fifth layer were selected.

For each selected cell a video recording was taken, using an Amscope $10 \mathrm{Mpx}$ microscope digital camera on an Axiostar Plus Zeiss light microscope, analyzed and converted into multiple image sequences of 200 serial digital images applying the Image J application. They were then imported in the Neuromantic application as image stacks in order to be used for semi-automatic three dimensional neuronal reconstructions. Neuronal tracing was carried out by 5 different individuals in order to avoid experimental bias.

Branch orders were evaluated in an adapted centrifugal fashion as follows: dendrites arising from the cell body were considered as first-order segments until they bifurcated symmetrically into second-order segments; dendritic branches arising from the first-order segments were considered as second-order segments until they bifurcated symmetrically into third-order segments, and so on.

Variables analyzed were the total dendritic length, the total number of dendritic segments and bifurcations, the dendritic tree asymmetry, as well as the length and the number of dendritic segments per order. Furthermore, the tracings were analyzed quantitatively using the Image J program according to Sholl's method of concentric circles [53]. Concentric cycles were drawn, at intervals of $15 \mu \mathrm{m}$ centered on the cell bodies, and dendritic intersections within each cycle were counted.

For the estimation of qualitative and quantitative changes of the dendrites we used magnifications of 400x.

Spine counts were carried out on the dendrites of layer $\mathrm{V}$ pyramidal neurons, on the basis of 300 photomicrographs. Visible spines were counted on three segments of the dendritic field. The first segment, 20-30 $\mu \mathrm{m}$ in length, was located on a basal dendrite; the second segment, 20-30 $\mu \mathrm{m}$ in length, was located on a horizontal branch of the apical dendrite; and the third one, 40-50 $\mu \mathrm{m}$, was located along the apical dendrite. For each of the segments described above, 20 serial digital pictures were taken and used in the Neuromantic application for the three dimensional representation of the segments including the dendritic spines.
Adjacent samples of the visual cortex were used for Nissl staining for estimation of the borders of cortical layers and the depth of the selected neurons in the visual cortex.

For the statistical analysis, Student's $t$ test was performed. Significance was taken as $p<0.05$.

\section{Results}

Golgi-stained tissue did not exhibit irregular varicose enlargements or constriction of dendrites, which were described as autolytic changes by Williams et al. (1978) [64].

\section{Qualitative and quantitative observations}

\section{Qualitative features}

Two types of pyramidal cells were observed (Fig. 1). The first one refers to corticocortical neurons, having small to medium sized cell somata and an apical dendrite which terminates in layers $2 / 3$, and the second one refers to corticotectal pyramidal cells, having large cell somata and an apical dendrite which ends in layer I. Both types of pyramidal neurons carry the standard morphology described by previous studies.

Application of silver impregnation technique revealed significant restriction of the dendritic arborization in aged individuals. Irregular swellings in the soma, as well as in the proximal portions of the apical dendrite and the axon, were observed.

\section{Quantitative changes}

The number of tertiary and quaternary branches of the basal dendrites was severely decreased mainly in small pyramidal cells of the older group (Fig. 2A and B). The total number of horizontal dendritic branches was also significantly lower in the above-mentioned group (Fig. 2C).

The total dendritic length was significantly lower in the aged group, being most prominent in the distal branches of small corticocortical pyramidal cells (Fig. 2D). Total number of bifurcations per neuron and the number of terminal branches were also decreased in the pyramidal cells of aged brains, exhibiting statistical significance in small cells but not in the large ones (Fig. 2A and B).

Sholl analysis revealed significant restriction of the dendritic field in the distal intersections, both in 


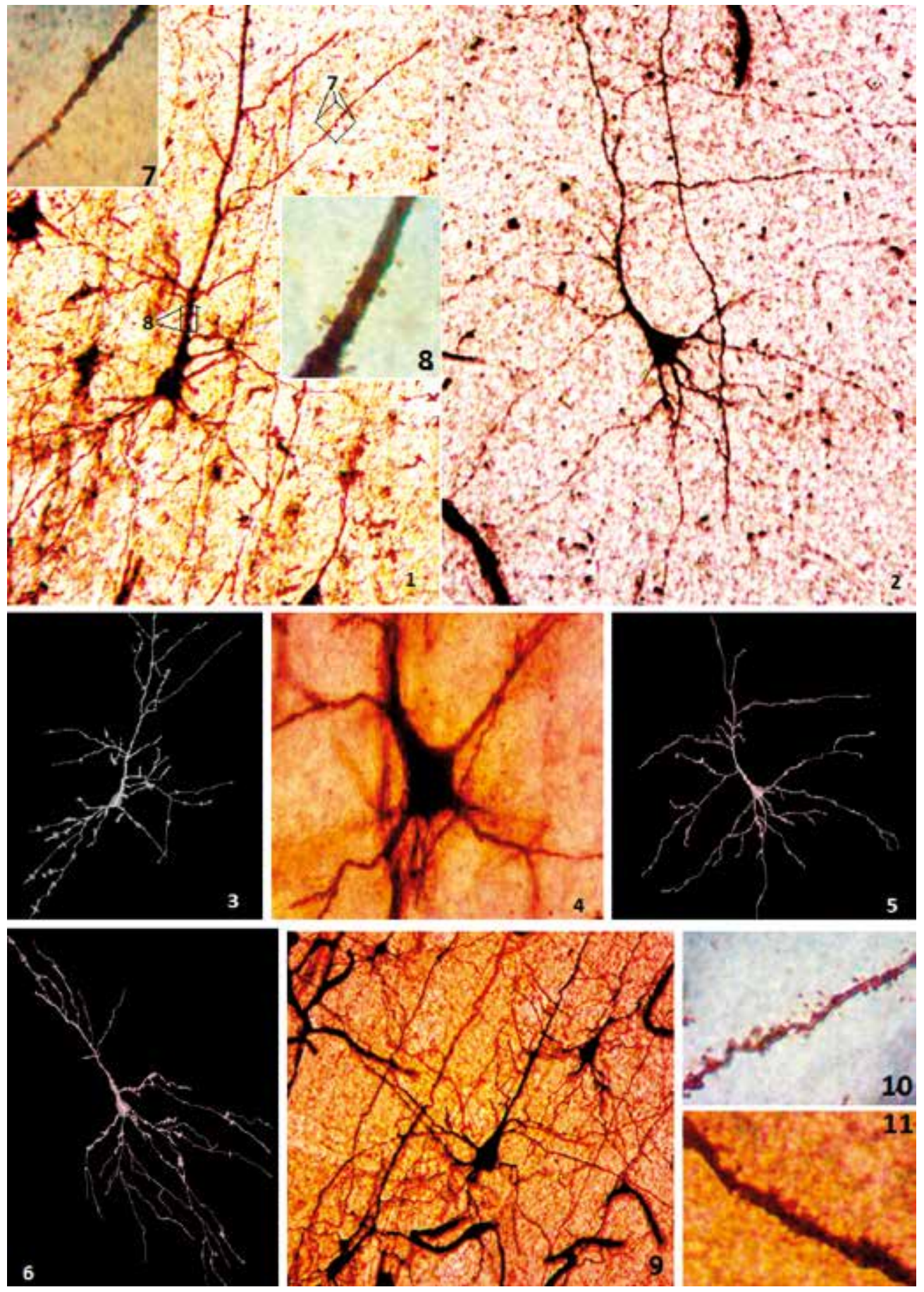

Fig. 1. Corticotectal [1] and corticocortical [2] pyramidal neurons from the older brains (Golgi method, magnification 100x) and their reconstructions [3] and [5]. Cell soma of a corticotectal pyramidal neuron from an older brain [4] exhibiting significant loss of basal dendritic branches and dendritic spines (Golgi method, magnification 400x). Reconstruction from a corticocortical neuron from a younger brain [6]. Higher magnification of an oblique dendritic segment of the neuron in Figure 1.1 [7] and higher magnification of a part of the apical dendrite of the same neuron [8] (Golgi method, magnification 1000x). Corticocortical pyramidal neuron from the visual cortex of an older brain [9], higher magnification of a basal [10] and an apical dendritic segment [11] of younger brains exhibiting higher spinal density than the older ones. 
large cells and in small to medium sized pyramidal cells (Fig. 2E and F).

The average length per branching order was severely decreased in the $3^{\text {rd }}$ and $4^{\text {th }}$ ordered branches of the small pyramidal cells of the older group, while the respective differences in the large pyra-

\section{A}

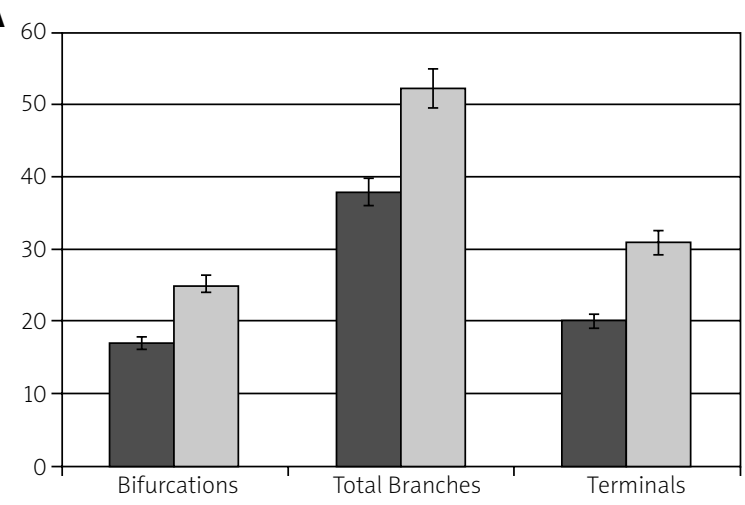

C

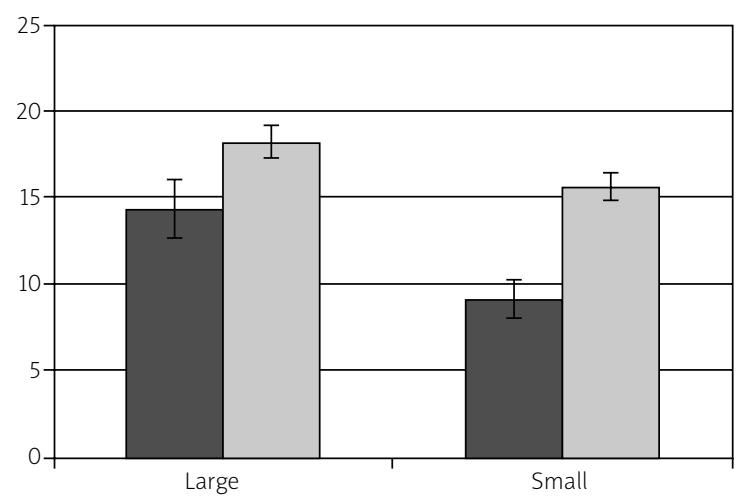

E

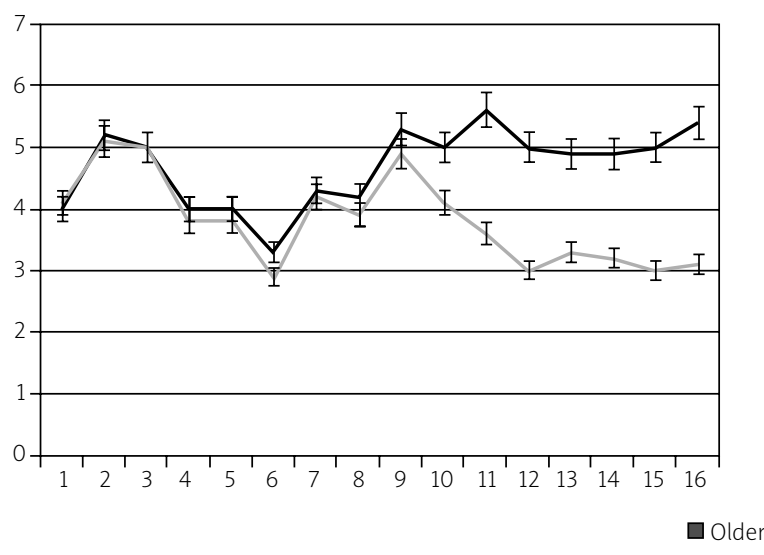

midal cells exhibited statistical significance only in the $4^{\text {th }}$ and higher ordered branches (Fig. $3 \mathrm{~A}$ and B). The same holds true for the dendritic branches per order (Fig. 3C and D).

No significant differences were detected in the dendritic tree asymmetry of small and large pyrami-

B

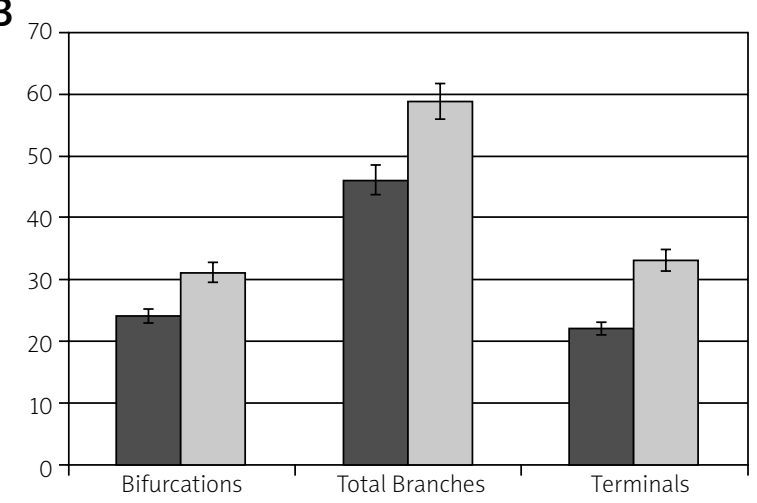

$D_{4}$

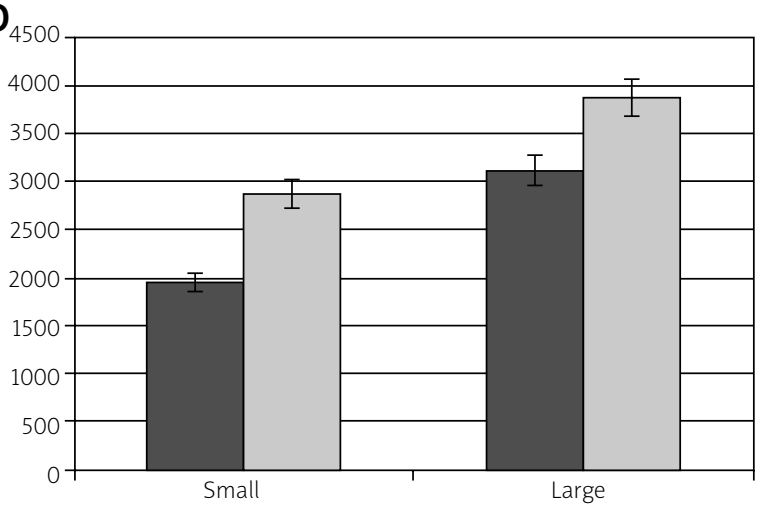

$\mathbf{F}$

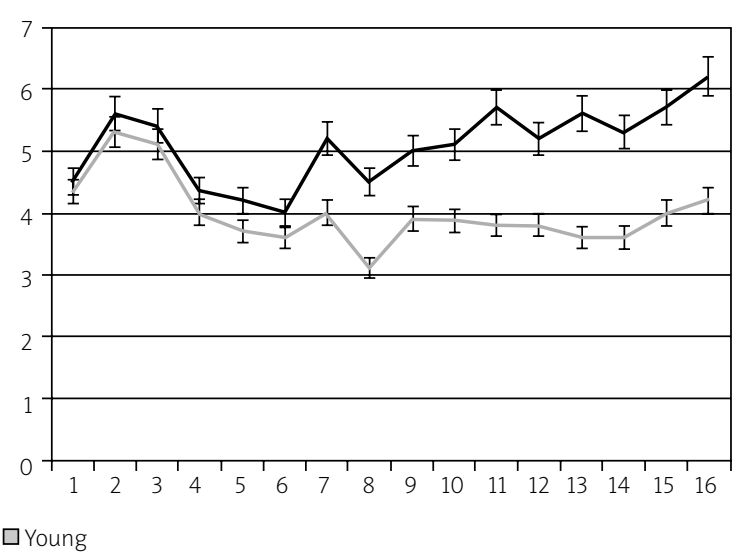

Fig. 2. Comparison of complexity of the dendritic arborizations of small (corticotectal) (A) and large (corticocortical) (B) pyramidal cells from younger and older individuals. Total number of horizontal branches of large and small pyramidal cell from younger and older individuals (C). Total dendritic length of small and large pyramidal cells from the visual cortex of younger and older individuals (D). Sholl analysis from small (E) and large (F) pyramidal cells from younger and older individuals. 
dal cells in both groups of the study; however, the daughter ratio was significantly lower in the older group (Fig. 3E and F). The average branching order was also lower in the older group (Fig. 4A).

\section{Dendritic spines}

At every age, the spine density for the thick dendrites was higher than that of the thinner dendrites.
Spinal density was calculated to be markedly decreased in both pyramidal cell types of the older group (Fig. 4B and C).

\section{Pyramidal cell type differences}

Small corticocortical pyramidal cells were more profoundly affected by age, while most of the age-related changes of the morphometric variables
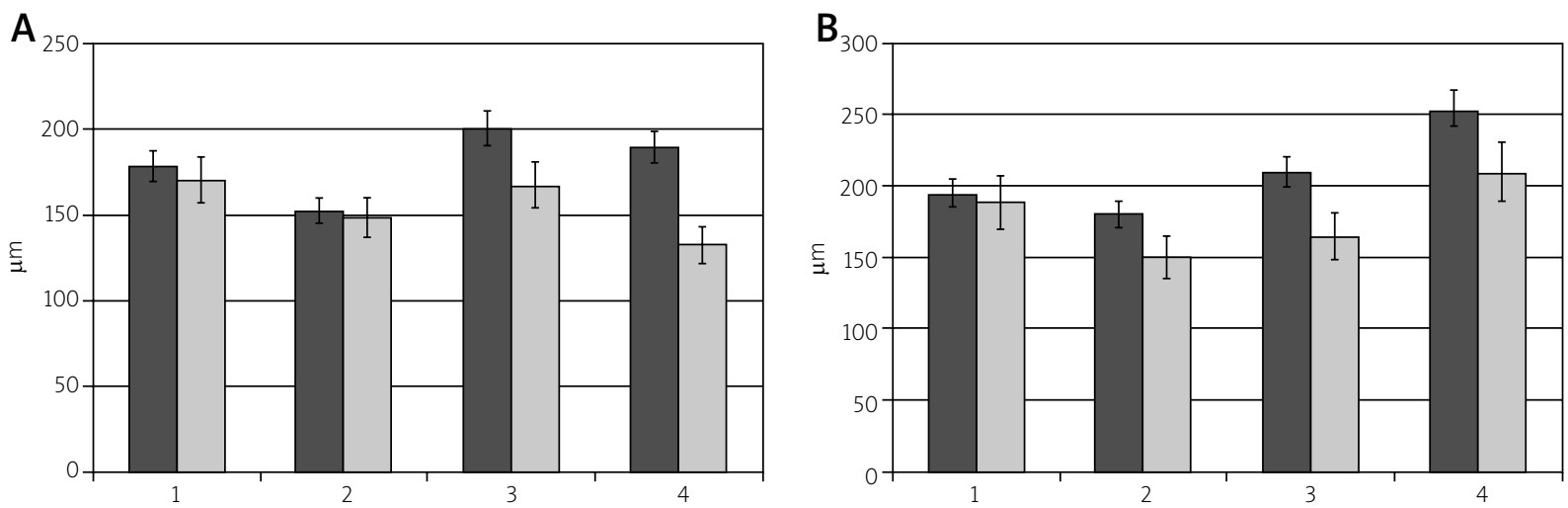

C

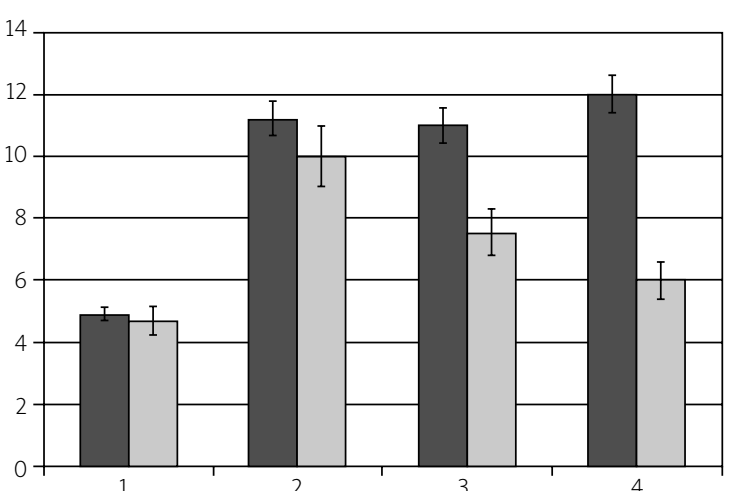

D

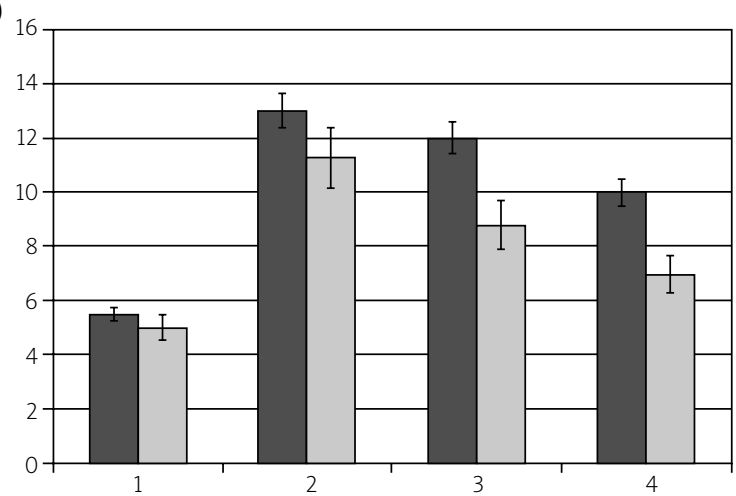

E
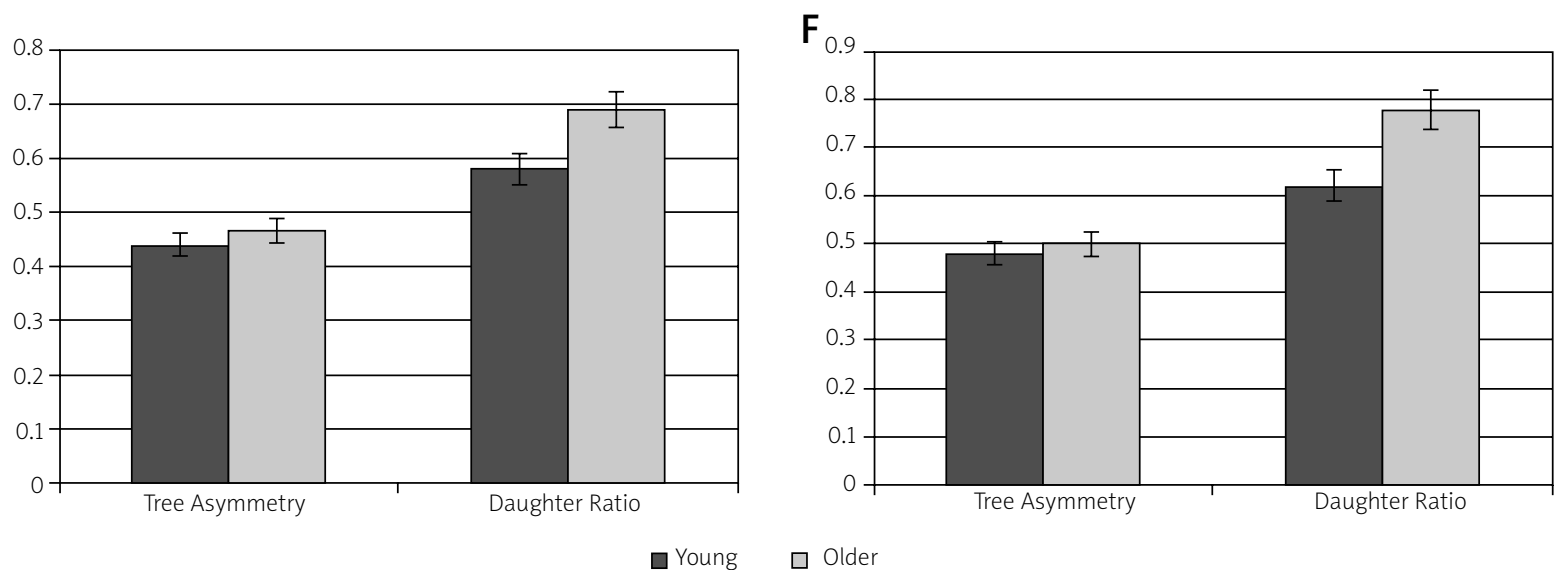

Fig. 3. Dendritic length per order and branches per order from small (A, C) and large (B, D) pyramidal cells from the visual cortex of younger and older individuals. Tree asymmetry and daughter ratio from small (E) and large (F) pyramidal cells from younger and older individuals. 
A

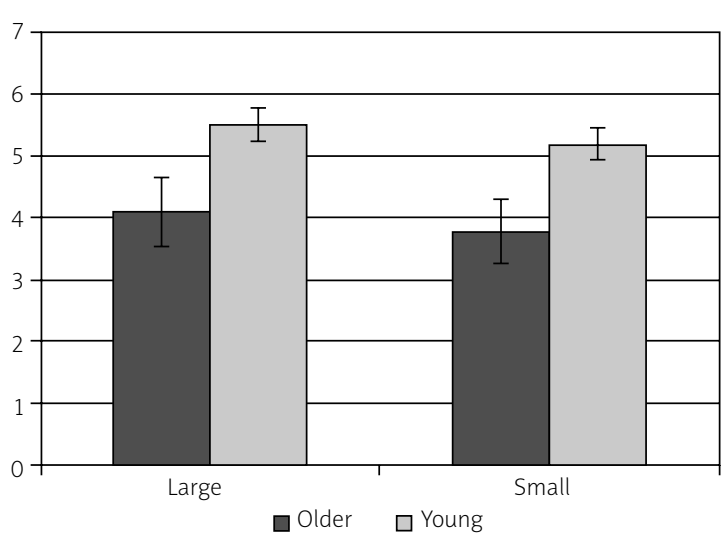

C

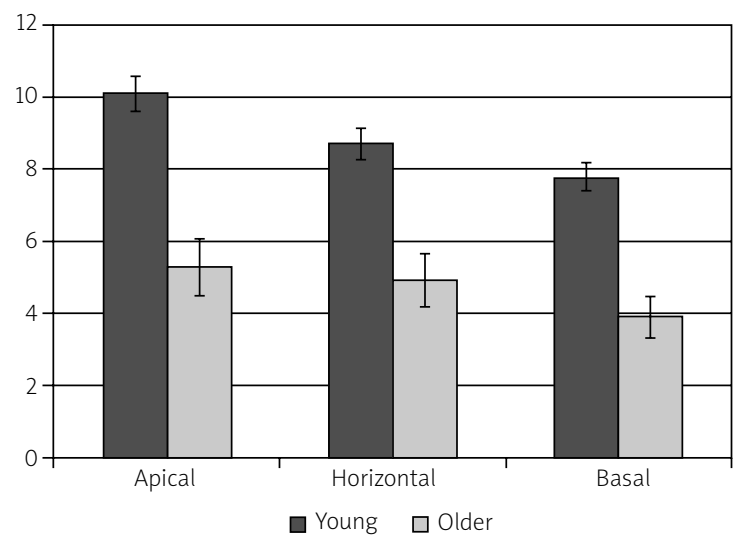

B

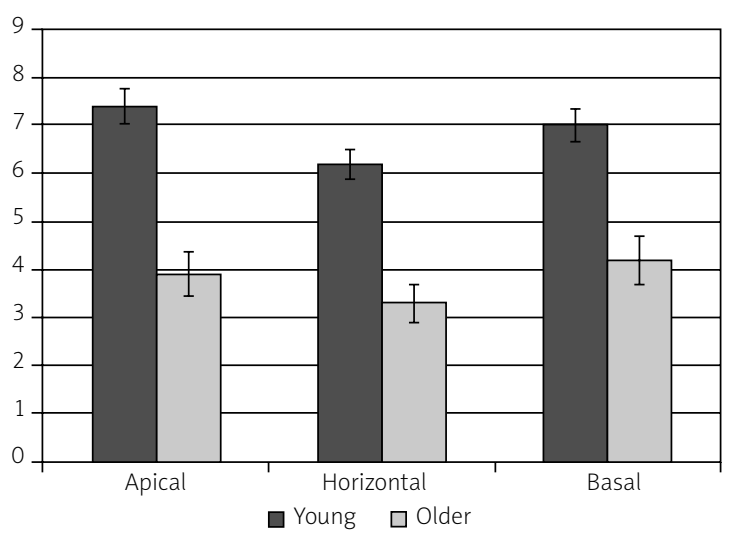

$\mathbf{D}_{50}$

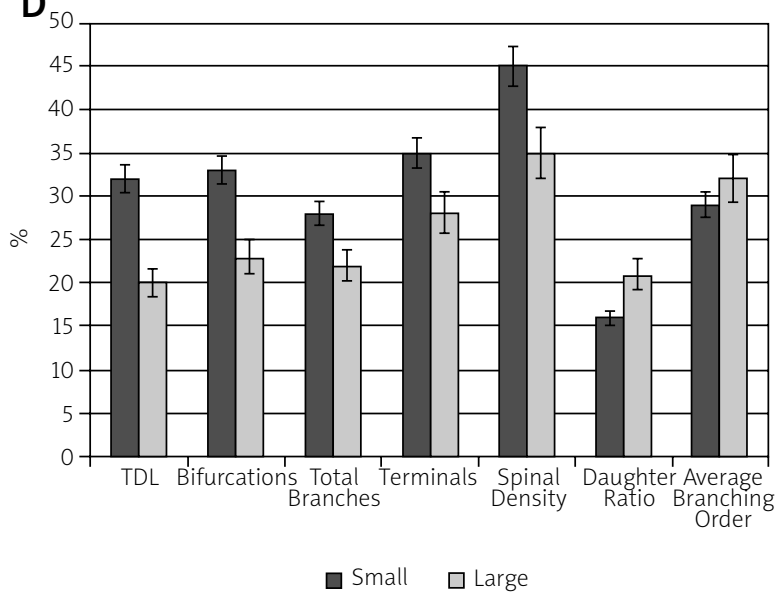

Fig. 4. Average branching orders (A), spinal density from small (B) and large (C) pyramidal cells. Comparison of age-related alterations of small and large pyramidal cells of the visual cortex (D).

studied are more evident in them, as can be seen in Fig. 4D.

\section{Discussion}

\section{Methodological considerations}

Golgi staining is a capricious and unpredictable method; however, it has been used for more than 100 years for the study of neuronal morphology and continues to provide a unique view of the neuronal cell soma, dendrites and dendritic spines [33].

The Neuromantic program which was used for the three dimensional neuronal reconstruction is a free application, verified and established for the semi-automatic reconstruction of neurons for single images or image stacks. Furthermore, it can be run by multiple computers simultaneously in more than one computer, allowing as many reconstructions as required in parallel [36].
The three-dimensional neuronal reconstruction allows a better and more accurate depiction of the neuron, its dendrites and dendritic spines. Therefore it can provide the researcher information about neuronal functionality and allows statistical comparison between experimental neuronal populations as well as functional simulation of traced neurons [60].

Light microscopy inherently underestimates branch and spine numbers, and therefore dendritic and spinal differences may actually be greater than observed [18,22]. However, the results are still acceptable as the same methods have been used in both groups of the study.

\section{Age-related changes}

Several aspects of age-related visual impairment have been reported during the past decades in studies concerning both humans and other mam- 
mals. Some of them refer to visual acuity, impairment of binocular summation, motion direction detection and spatial frequency contrast sensitivity $[14,29,40,47,51,57,63]$.

Many studies have demonstrated age-related regression in the dendritic arbors and spines of pyramidal neurons located in the prefrontal, superior temporal and precentral cortices in humans $[29,37,43]$ and in nonhuman primates [46].

Significant age-related loss of dendrites and dendritic spines was first described in human brain by Scheibel and coworkers, including both shorter and fewer dendritic branches [52].

The effects of aging on dendritic complexity and spinal density of cortical pyramidal neurons in the human brain have also been examined by Anderson and Rutledge (1996), who quantified spine numbers on the basal dendrites of supragranular pyramidal cells in the posterior temporal gyrus and noted a significant decline between 21 and 71 years of age [2]. Moreover, Jacobs and coworkers examined the total dendritic spine number on basal dendrites of supragranular pyramidal cells in prefrontal area 10 and the occipital area in 26 neurologically normal individuals 14-106 years old and reported a $46 \%$ decrease in spine numbers and spine density from the younger to the older group [22].

In the present study spinal density was significantly lower in the apical and basal dendrites of the pyramidal neurons of the aged group. These results are congruent with the study of Page et al. (2002), who demonstrated a decrease of $28-37 \%$ in the basal and apical dendrites of aged animals compared to young ones [41].

Total dendritic length, dendritic length per branching order and total number of terminal branches were also significantly lower in the pyramidal cells of the older group. Animal studies have also found regressive dendritic changes during normal aging in prefrontal area 46 [13] and in the visual cortex [51].

As Sholl analysis revealed, distal segments are mainly affected by age.

Significant age-related decreases in segment numbers were observed at the second branch order for apical dendrites and at the tertiary and quaternary order for basal dendrites. Similar changes have been demonstrated in age-related animal studies in other cortical areas and in area $17[13,41]$. The outermost branches of the dendritic tree are the most plastic ones and contribute significantly to synap- tic integration locally and along the entire neuron. The most peripheral dendritic spines are thought to be particularly effective in adjusting potential [23]. Thus the excitability of an entire dendrite may be disproportionately regulated by changes in distal dendrites and dendritic branches.

Although mechanisms underlying age-related changes have not yet been clearly defined, a number of biochemical and genetic alterations have been described during normal aging. Aging is characterized by downregulation of specific genes, such as genes expressing calcium channel subunits, GABA receptor subunits and genes involved in synaptic plasticity and playing a role in DNA repair mechanisms and antioxidant defense [3,21,24,39,62].

Electron microscope studies demonstrated a correlation between oxidative stress and neuronal morphological alterations [4].

Furthermore, a reduction of MAP-2 protein expression and brain-derived neurotrophic factor abnormalities has also been revealed by recent studies, offering a possible etiological background for the age-related changes [9].

Although aged cerebral cortex still display a certain degree of neuronal plasticity, the selective loss of distal dendritic branches and age-related alterations of dendritic spines point to a reduced tolerance of the aged visual cortex towards vascular and biochemical changes.

\section{Cell-specific alterations}

Small pyramidal cells of layer $V$ are mainly affected by age, while large pyramidal cells retain higher dendritic and spinal density. The statistical test performed for the comparison of the morphometric changes between the two subpopulations of pyramidal cells confirmed this hypothesis.

The main differences between the subgroups are related to the size of the cell soma, the functionality and their afferent and efferent connections.

Medium sized to large pyramidal cells have thick axons ramifying with collaterals projecting to the superior colliculus [20]. Small to medium sized pyramidal cells are also located at the depth of layer 5 , possess basal dendrites that branch in layer 5 and layer 6 as well, and an apical dendrite never reaches the molecular layer. Their axons send recurrent axons to layer 3A [30], to layers 5 and 6, and form efferents to cortical area $\mathrm{V} 2$. The different patterns 
of connections might play a role in the differences detected in two subpopulations of pyramidal cells detected in the present study.

These findings are consistent with those of a previous study on area 46 , where small corticocortical pyramidal neurons seem to be mainly affected by age in comparison to large projection neurons [13].

\section{Conclusions}

In conclusion, the present study points to the fact that brain aging is accompanied by rather subtle morphological and molecular changes at the level of single neuronal populations and different types of pyramidal cells of the human visual cortex are differently affected. The loss of dendrites and dendritic spines leads to a substantial decrease of the synaptic contacts of the cells of the visual cortex with the neurons of other cortical and subcortical areas implicated in the modulation of the visual information.

These alterations seen in the thick sections of the silver-impregnated preparations, attributed to the degeneration of the dendritic spines, may explain the impaired central visual function during normal aging.

\section{Disclosure}

\section{Authors report no conflict of interest.}

\section{References}

1. Ahmad A, Spear PD. Effects of aging on the size, density, and number of rhesus monkey lateral geniculate neurons. J Comp Neurol 1993; 334: 631-643.

2. Anderson B, Rutledge V. Age and hemisphere effects on dendritic structure. Brain 1996; 119: 1983-1990.

3. Anderton B. Ageing of the brain. Mech Ageing Dev 2002; 123: 811-817.

4. Baloyannis SJ, Costa V, Mauroudis I, Psaroulis D, Manolides SL, Manolides LS. Dendritic and spinal pathology in the acoustic cortex in Alzheimer's disease: morphological and morphometric estimation by Golgi technique and electron microscopy. Acta Otolaryngol 2007; 127: 351-354.

5. Baracat B, Marquie JC. Age differences in sensitivity, response bias, and reaction time on a visual discrimination task. Exp Aging Res 1992; 18: 59-66.

6. Becker LE, Armstrong DL, Chan F, Wood MM. Dendritic development in human occipital cortical neurons. Brain Res 1984 315: 117-124.

7. Brody H. Organisation of the cerebral cortex III. A study of aging in the human cerebral cortex. J Comp Neurol 1955; 102: 511-556.

8. Callaway EM. Local circuits in primary visual cortex of the macaque monkey. Annu Rev Neurosci 1998; 21: 47-74.
9. Chauhan N, Siegel G. Age-dependent organotypic expression of microtubule-associated proteins (MAP1, MAP2, and MAP5) in rat brain. Neurochem Res 1997; 22: 713-719.

10. de Brabander JM, Kramers RJ, Uylings HB. Layer-specific dendritic regression of pyramidal cells with ageing in the human prefrontal cortex. Eur J Neurosci 1998; 10: 1261-1269.

11. Dekaban AS. Mental retardation and neurologic involvement with congenital retinal blindness. Dev Med Child Neurol 1972; 14: 436-444.

12. Double K, Halliday G, Kril J, Harasty J, Cullen K, Brooks W, Creasey H, Broe G. Topography of brain atrophy during normal aging and Alzheimer's disease. Neurobiol Aging 1996; 17: 513-521.

13. Duan H, Wearne SL, Rocher AB, Macedo A, Morrison JH, Hof PR. Age-related dendritic and spine changes in corticocortically projecting neurons in macaque monkeys. Cereb Cortex 2003; 13: 950-961.

14. Elliott D, Whitaker D, MacVeigh D. Neuralcontribution to spatiotemporal contrast sensitivity decline in healthy ageing eyes. Vision Res 1990; 30: 541-547.

15. Hallman LE, Schofield BR, Lin CS. Dendritic morphology and axon collaterals of corticotectal, corticopontine, and callosal neurons in layer 5 of primary visual cortex of the hooded rat. J Comp Neurol 1988; 272: 149-160.

16. Harting JK, Updyke BV, Van Lieshout DP. Corticotectal projections in the cat: anterograde transport studies of twenty-five cortical areas. J Comp Neurol 1992; 324: 379-414.

17. Holländer H, Schönitzer K. Corticotectal terminals in the superior colliculus of the rabbit: a light- and electron microscopic analysis using horseradish peroxidase (HRP)-tetramethylbenzidene (TMB). J Comp Neurol 1983; 219: 81-87.

18. Horner $\mathrm{CH}$, Arbuthnott E. Methods of estimation of spine density - are spines evenly distributed throughout the dendritic field? J Anat 1991; 177: 179-184.

19. Hua T, Li X, He L, Zhou Y, Wang Y, Leventhal AG. Functional degradation of visual cortical cells in old cats. Neurobiol Aging 2006; 27: 155-162.

20. Hübener M, Schwarz C, Bolz J. Morphological types of projection neurons in layer 5 of cat visual cortex. J Comp Neurol 1990; 301: 655-674.

21. Iyo T, Yamasaki T. The detection of age-related decrease of dopamine, D1, D2 and serotonin 5-HT2 receptors in living human brain. Prog Neuro-Psycopharmacol Biol Psychiatry 1993; 17: 415-421.

22. Jacobs B, Driscoll L, Schall M. Life-span dendritic and spine changes in areas 10 and 18 of human cortex: a quantitative Golgi study. J Comp Neurol 1997; 386: 661-680.

23. Jaslove SW. The integrative properties of spiny distal dendrites. Neuroscience 1992; 47: 495-519.

24. Kaasinen V, Vilkman H, Hietala J, Någren K, Helenius H, Olsson H, Farde L, Rinne JO. Age-related dopamine D2/D3 receptor loss in extrastriatal regions of the human brain. Neurobiol Aging 2000; 21: 683-688.

25. Kasper EM, Larkman AU, Lubke J, Blakemore C. Pyramidal neurons in layer 5 of the rat visual cortex. I. Correlation among cell morphology, intrinsic electrophysiological properties, and axon targets. J Comp Neurol 1994; 339: 459-474. 
26. Keizer K, Kuypers HG, Ronday HK. Branching cortical neurons in cat which project to the colliculi and to the pons: a retrograde fluorescent double-labeling study. Exp Brain Res 1987; 67: 1-15.

27. Kim CB, Tom BW, Spear PD. Effects of aging on the densities, numbers, and sizes of retinal ganglion cells in rhesus monkey. Neurobiol Aging 1996; 17: 431-438.

28. Kline DW, Schieber F, Abusamra LC, Coyne AC. Age, the eye, and the visual channels: contrast sensitivity and response speed. J Gerontol 1983; 38: 211-216.

29. Logan JM, Sanders AL, Snyder AZ, Morris JC, Buckner RL. Underrecruitment and nonselective recruitment: dissociable neural mechanisms associated with aging. Neuron 2002; 33: 827-840.

30. Lund JS, Boothe RG. Interlaminar connections and pyramidal neuron organization in the visual cortex, area 17 , of the macaque monkey. J Comp Neurol 1975; 159: 305-334.

31. Mavroudis IA, Fotiou DF, Adipepe LF, Manani MG, Njau SD, Psaroulis D, Costa VG, Baloyannis SJ. Morphological changes of the human Purkinje cells and deposition of neuritic plaques and neurofibrillary tangles on the cerebellar cortex of Alzheimer's disease. Am J Alzheimers Dis Other Demen 2010; 25: 585-591.

32. Mavroudis IA, Fotiou DF, Manani MG, Njaou SN, Frangou D, Costa VG, Baloyannis SJ. Dendritic pathology and spinal loss in the visual cortex in Alzheimer's disease: a Golgi study in pathology. Int J Neurosci 2011; 121: 347-354.

33. Mavroudis I, Petrides F, Manani M, Theocharides C, Ciobica A Padurariu M, Kiourexidou M, Njau S, Costa V, Baloyannis S. Dendritic and spinal alterations of the spiny stellate cells of the human visual cortex during normal aging. Folia Neuropatho 2012; 50: 261-269.

34. Mcllwain JT. Topographic relationships in projection from striate cortex to superior colliculus of the cat. J Neurophysiol 1973 36: 690-701

35. Mrzljak L, Uylings HBM, Kostović I, van Eden CG. Prenatal development of neurons in the human prefrontal cortex. II. A quantitative Golgi study. J Comp Neurol 1992; 316: 485-496.

36. Myatt DR, Nasuto SJ. Three-Dimensional Reconstruction of Neurons with Neuromantic. AISB Quarterly 2008; 125: 1-2.

37. Nakamura S, Akiguchi I, Kameyama M, Mizuno N. Age-related changes of pyramidal cell basal dendrites in layers III and $V$ of human motor cortex: a quantitative Golgi study. Acta Neuropathol 1985; 65: 281-284.

38. Nomura H, Ando F, Niino N, Shimokata H, Miyake Y. Age-related change in contrast sensitivity among Japanese adults. Jpn J Ophthalmol 2003; 47: 299-303.

39. Ota M, Yasuno F, Ito H, Seki C, Kozaki S, Asada T, Suhara T. Age-related decline of dopamine synthesis in the living human brain measured by positron emission tomography with $L-[\beta$ 11C]DOPA. Life Sci 2006; 79: 730-736.

40. Owsley C, Sekuler R, Boldt C. Aging and low-contrast vision: face perception. Investig Ophthalmol Vis Sci 1981; 21: 362-365.

41. Page TL, Einstein M, Duan H, He Y, Flores T, Rolshud D, Erwin JM Wearne SL, Morrison JH, Hof PR. Morphological alterations in neurons forming corticocortical projections in the neocortex of aged Patas monkeys. Neurosci Lett 2002; 317: 37-41.

42. Pakkenberg B, Gundersen HJG. Neocortical neuron number in humans: effects of sex and age. J Comp Neurol 1997; 384: 312-320.
43. Park DC, Polk TA, Park R, Minear M, Savage A, Smith M R. Aging reduces neural specialization in ventral visual cortex. PNAS 2004; 101: 13091-13095.

44. Peters A. Aging in monkey cerebral cortex. In: Cerebral cortex, Vol. 9, Normal and altered states of function. Peters A, Jones EG (eds.). Plenum Press, New York 1991, pp. 485-510.

45. Peters A, Sethares C. Aging and the Meynert cells in rhesus monkey primary visual cortex. Anat Rec 1993; 236: 721-729.

46. Peters A, Sethares C, Moss MB. The effects of aging on layer 1 in area 46 of prefrontal cortex in rhesus monkey. Cereb Cortex 1998; 8: 671-684.

47. Ross JE, Clarke DD, Bron AJ. Effect of age on contrast sensitivity function: uniocular and binocular findings. Br J Ophthalmol 1985; 69: 51-56.

48. Rumberger A, Schmidt M, Lohmann H, Hoffman K-P. Correlation of electrophysiology, morphology, and functions in corticotectal and corticopretectal projection neurons in rat visual cortex. Exp Brain Res 1998; 119: 375-390.

49. Samorajski T. How the human brain responds to aging. J Am Geriat Soc 1976; 24: 4-11.

50. Satorre J, Cano J, Reinoso-Suarez F. Stability of the neuronal population of the dorsal lateral geniculate nucleus (LGNd) of aged rats. Brain Res 1985; 339: 375-377.

51. Schefrin BE, Tregear SJ, Harvey Jr LO, Werner JS. Senescent changes in scotopic contrast sensitivity. Vision Res 1999; 39: 3728-3736.

52. Scheibel ME, Lindsay RD, Tomiyasu U, Scheibel AB. Progressive dendritic changes in aging human cortex. Exp Neurol 1975; 47: 392-403.

53. Sholl DA. Dendritic organization in the neurons of the visual and motor cortices of the cat. J Anat 1953; 87: 387-406.

54. Swadlow HA. Influence of VPM afferents on putative inhibitory interneurons in S1 of the awake rabbit: evidence from cross-correlation, microstimulation, and latencies to peripheral sensory stimulation. J Neurophysiol 1995; 73: 1584-1599.

55. Takashima S, Chan F, Becker LE, Armstrong DL. Morphology of the developing visual cortex of the human infant: a quantitative and qualitative Golgi study. J Neuropathol Exp Neurol 1980; 39: 487-501.

56. Tigges J, Herndon JG, Peters A. Neuronal population of area 4 during the life span of the rhesus monkey. Neurobiol Aging 1990; 11: 201-208.

57. Tran DB, Silverman SE, Zimmerman K, Feldon SE. Age-related deterioration of motion perception and detection. Graefes Arch Clin Exp Ophthalmol 1998; 236: 269-273.

58. Tsiola A, Hamzei-Sichani F, Peterlin Z, Yuste R. Quantitative morphologic classification of layer 5 neurons from mouse primary visual cortex. J Comp Neurol 2003; 461: 415-428.

59. Uylings HBM, de Brabander JM Neuronal changes in normal human aging and Alzheimer's disease. Brain Cogn 2002; 49: 268-276.

60. Van Pelt J, Van Galen E, Wolters P, Ramakers GJA, Vajda I. Effects of low-frequency stimulation on spontaneous firing dynamics in dissociated cortical cultures on multi-electrode arrays. Proceedings MEA Meeting 2006, BIOPRO edition vol. 3, BIOPRO Baden-Wurttemberg Gmbh, Stuttgart 2006, pp. 19-21. 
Ioannis A. Mavroudis, Marina G. Manani, Foivos Petrides, Dimitrios Dados, Alin Ciobica, Manuela Padurariu, Konstantina Petsoglou, Samuel N. Njau, Vasiliki G. Costa, Stavros J. Baloyannis

61. Vincent SL, Peters A, Tigges J. Effects of aging on the neurons within area 17 of rhesus monkey cerebral cortex. Anat Rec 1989; 223: 329-341.

62. Wang, Y, Chan GLY, Holden J E, Dobko T, Mak E, Schulzer M, Huser JM, Snow BJ et al. Age-Dependent Decline of Dopamine D1 Receptors in Human Brain: A PET Study. Synapse 1998; 30: 56-61.

63. Weale RA. Senile changes in visual acuity. Trans Ophthalmol Soc UK 1975; 95: 36-38.

64. Williams RS, Ferrante RJ, Caviness VS Jr. The Golgi rapid method in clinical neuropathology: morphological consequences of suboptimal fixation. J Neuropathol Exp Neurol 1978; 37: 13-33.

65. Xu YH, Wang H, Chen Q, Zhou YF. Age and Sex-related changes of the visual cortex of the rat. Zool Res 2007; 28: 297-302. 